DIMENSI, VOL. 8, NO. 2 : 286-306

JULI 2019

ISSN: 2085-9996

\title{
EVALUASI PROGRAM KAMPUNG KELUARGA BERENCANA DI KOTA TANJUNGPINANG
}

\section{EVALUATION OF THE FAMILY PLANNING VILLAGE PROGRAM IN TANJUNGPINANG}

\author{
Faizal Rianto ${ }^{1}$, Neng Suryanti Nengsih ${ }^{2}$, Rendra Setyadiharja ${ }^{3}$ \\ ${ }^{I}$ (Administrasi Publik, STISIPOL Raja Haji, Indonesia) \\ ${ }^{2}$ (Ilmu Pemerintahan, STISIPOL Raja Haji, Indonesia) \\ ${ }_{3}^{3}$ (Ilmu Pemerintahan, STISIPOL Raja Haji, Indonesia) \\ Ifaizalrianto@gmail.com; ${ }^{2}$ suryatra@yahoo.com; ${ }^{3}$ rendra_tanjungpinang@yahoo.co.id
}

\begin{abstract}
Abstrak
Kegiatan yang dilakukan oleh Program Kampung Keluarga Berencana (Kampung KB) tidak hanya identik dengan penggunaan dan pemasangan alat kontrasepsi, akan tetapi program tersebut merupakan sebuah program pembangunan terpadu dan terintegrasi dengan berbagai program pembangunan lainnya. Program Kampung KB dipersepsikan sebagai program pengendalian jumlah anak serta identik dengan alat kontrasepsi/alat KB, sedangkan aspek kependudukan, pembangunan keluarga, maupun aspek lintas sektor Kampung KB diketahui dan dipahami namun dengan terbatas juga. Masyarakat Kampung KB menerima pelayanan KB dan pelayanan kesehatan disamping mengikuti kegiatankegiatan yang dilaksanakan di Kampung KB seperti kegiatan advokasi dan komunikasi, informasi, dan edukasi (KIE) serta kegiatan-kegiatan lainnya yang dilaksanakan oleh kelompok-kelompok kegiatan di Kampung KB. Disamping itu, kegiatan lintas sektor seperti pendataan dan pembuatan akte kelahiran dan Kartu Tanda Penduduk (KTP) berkerjasama dengan Dinas Kependudukan dan Catatan Sipil (DISDUK CAPIL) Kota Tanjungpinang, menunjukkan adanya kerjasama lintas sektoral yang terbangun walaupun terbatas pada aspek-aspek lintas sektoral tertentu. Salah satu tantangan Program Kampung KB adalah minimnya dukungan anggaran. Keengganan masyarakat untuk menjadi kader Kampung KB dalam PPKBD/Sub-PPKBD atau terlibat dalam POKJA Kampung KB, dapat diatribusikan pada minimnya insentif atau stimulan finansial yang tersedia bagi para kader Kampung KB. Disamping itu, tantangan lainnya adalah dalam bentuk sarana operasional seperti bangunan sekretariat Kampung KB yang walaupun tersedia masing-masing Kampung KB, Kampung KB yang menumpang pada bangunan lainnya seperti POSYANDU, POLINDES, Balai Penyuluhan, atau bangunan lainnya.
\end{abstract}

Kata Kunci: keluarga berencana; kebijakan; program; pemberdayaan keluarga

Abstrct
The activities carried out by the Family Planning Village Program (KB Village) are not only
identical to the use and installation of contraceptives, but the program is an integrated
development program and is integrated with various other development programs. The KB
Village Program is perceived as a program to control the number of children and is identical
to contraception / family planning devices, while the aspects of population, family
development, as well as cross-sector aspects of the KB Village are known and understood, but
with limited limitations. The KB Kampung community receives family planning services and
health services in addition to participating in activities carried out in KB Village such as
advocacy and communication, information, and education (IEC) activities as well as other
activities carried out by the activity groups in KB Village. In addition, cross-cutting activities
such as data collection and birth certificates and Identity Card (KTP) in collaboration with the
Office of Population and Civil Registration (DISDUK CAPIL) of Tanjungpinang City, show 
the existence of cross-sectoral cooperation that is developed even though it is limited to certain cross-sectoral aspects. One of the challenges of the KB Village Program is the lack of budget support. The reluctance of the community to become KB Family cadres in the PPKBD / Sub$P P K B D$ or be involved in the KB Village Working Group, can be attributed to the lack of financial incentives or stimulants available to $K B K B$ cadres. Besides that, other challenges are in the form of operational facilities such as the KB Village secretariat building which, although each KB Village is available, KB Village that hitches a ride on other buildings such as POSYANDU, POLINDES, Counseling Centers, or other buildings.

Keywords: family planning; Policy; program; family empowerment

\section{PENDAHULUAN}

Badan Kependudukan dan Keluarga Berencana Nasional (BKKBN) merupakan salah satu Kementerian/Lembaga (K/L) yang diberi mandat untuk mewujudkan Agenda Prioritas Pembangunan (Nawacita), terutama pada Agenda Prioritas nomor 5 (lima) yaitu meningkatkan kualitas hidup manusia Indonesia melalui pembangunan kependudukan dan keluarga berencana (RENSTRA BKKBN 2015-2019).

Untuk mendukung Agenda Prioritas Pembangunan tersebut, BKKBN telah menyusun sasaran strategis yang tertera pada Rencana Strategis BKKBN Tahun 2015-2019. Sasaran strategis tersebut adalah sebagai berikut: menurunnya Laju Pertumbuhan Penduduk (LPP) dari 1.38\% pada tahun 2015 menjadi 1.21\% pada tahun 2019; menurunnya Angka Kelahiran Total (TFR) per Wanita Usia Subur (15-49 tahun) dari 2.37 pada tahun 2015 menjadi 2.28 pada tahun 2019; meningkatnya pemakaian kontrasepsi (CPR) semua metode dari $65.2 \%$ pada tahun 2015 menjadi 66\% pada tahun 2019; menurunnya kebutuhan ber-KB yang tidak terpenuhi (unmet need) dari $10.60 \%$ pada tahun 2015 menjadi 9.91\% pada tahun 2019; menurunnya Angka Kelahiran pada remaja usia 15-19 tahun (ASFR 15-19 tahun) dari 46 per 100 kelahiran pada tahun 2015 menjadi 38 per 1000 kelahiran pada tahun 2019; serta menurunnya kehamilan yang tidak diinginkan dari Wanita Usia Subur (15-49 tahun) dari 7.1\% pada tahun 2015 menjadi $6.6 \%$ pada tahun 2019.

Undang-Undang Nomor 52 Tahun 2009 Tentang Perkembangan Kependudukan dan Pembangunan Keluarga kemudian mengamanatkan bahwa pembangunan nasional mencakup semua dimensi dan aspek kehidupan termasuk perkembangan kependudukan dan 
Pembangunan keluarga untuk mewujudkan masyarakat adil dan makmur yang dilaksanakan berdasarkan Pancasila dan Undang-Undang Dasar Negara Republik Indonesia Tahun 1945. Namun, terdapat dua isu utama yang perlu diperhatikan dalam integrasi penduduk dan pembangunan. Isu utama tersebut adalah: pertama, penduduk tidak hanya diperlakukan sebagai obyek tetapi juga sebagai subyek pembangunan; dan kedua, ketika penduduk memiliki peran sebagai subyek pembangunan, maka diperlukan upaya pemberdayaan untuk menyadarkan hak penduduk dan meningkatkan kapasitas penduduk dalam pembangunan (bkkbn.go.id).

Oleh sebab itu, maka, digagaslah Program Kampung Keluarga Berencana (Kampung KB). Melalui Kampung KB, diharapkan pelaksanaan Program Kependudukan, Keluarga Berencana, dan Pembangunan Keluarga (KKPBK) dan program-program pembangunan lainnya dapat berjalan secara terpadu dan bersamaan. Secara umum, tujuan dibentuknya Kampung KB adalah untuk meningkatkan kualitas hidup masyarakat di tingkat kampung atau yang setara melalui program KKBPK serta pembangunan sektor terkait lainnya dalam rangka mewujudkan keluarga kecil berkualitas. Sedangkan secara khusus, Kampung KB dibentuk untuk meningkatkan peran serta pemerintah, lembaga non-pemerintah, dan swasta dalam memfasilitasi, mendampingi, dan membina masyarakat untuk menyelenggarakan program KKBPK dan pembangunan sektor terkait, serta untuk meningkatkan kesadaran masyarakat tentang pembangunan berwawasan kependudukan (bkkbn.go.id).

Kampung KB juga dirancang sebagai upaya membumikan, mengangkat kembali, serta merevitalisasi program KKBPK guna mendekatkan akses pelayanan kepada keluarga dan masyarakat dalam upaya mengaktualisasikan dan mengaplikasikan fungsi-fungsi keluarga secara utuh dalam masyarakat. Dengan demikian, kegiatan yang dilakukan di Kampung KB tidak hanya identik dengan penggunaan dan pemasangan alat kontrasepsi, akan tetapi merupakan sebuah program pembangunan terpadu dan terintegrasi dengan berbagai program pembangunan lainnya (bkkbn.go.id).

Disamping itu, Kampung KB juga dapat menjadi wahana pemberdayaan masyarakat melalui berbagai macam program yang mengarah pada upaya merubah sikap, prilaku, dan cara berpikir (mindset) masyarakat kearah yang lebih baik, sehingga kampung yang tertinggal dan 
terbelakang dapat sejajar dengan kampung-kampung lainnya, masyarakat yang tidak memiliki kegiatan dapat bergabung dengan Kelompok Kegiatan (POKTAN) Kampung KB, dan keluarga yang tidak memiliki usaha dapat bergabung menjadi anggota Usaha Peningkatan Pendapatan Keluarga Sejahtera (bkkbn.go.id).

Namun begitu, kajian dan literatur mengenai Kampung KB sebagai wahana pemberdayaan masyarakat masih minim, begitu juga dengan kajian terhadap evaluasi program Kampung KB tersebut.Namun, hal itu bukan berarti bahwa kehadiran Kampung KB tidak memiliki dampak positif. Studi yang dilakukan oleh Mardiyono (2017) misalnya, menyimpulkan bahwa kehadiran Kampung KB dapat: meningkatkan frekuensi dan kualitas kegiatan advokasi dan kegiatan komunikasi, informasi, dan edukasi; meningkatkan pembentukan kelompok baru oleh Penyuluh Keluarga Berencana (PKB) dan Petugas Lapangan Keluarga Berencana (PLKB); serta meningkatkan peserta KB Metode Kontrasepsi Jangka Panjang (MKJP). Kehadiran Kampung KB juga diapresiasi oleh masyarakat dimana masyarakat merasa bahwa Program Kampung KB memiliki kepentingan yang besar dan memberikan manfaat kepada masyarakat (Setiawati, 2017).

Hanya saja, disamping dampak dan persepsi positif, Kampung KB juga memiliki kelemahan-kelemahan dimana Kampung KB belum dapat memenuhi indikator-indikator keberhasilan Program Kampung KB. Studi yang dilakukan oleh Zuhriah, Indarjo, \& Raharjo (2017) misalnya, mengungkapkan kelemahan Kampung KB, antara lain: jumlah kader belum maksimal karena merangkap tugas lain; anggaran belum tersedia untuk kegiatan Kampung KB sedangkan anggaran hanya tersedia untuk persiapan dan pembentukan Kampung KB; kegiatan tidak sesuai rencana awal; kurangnya sosialisasi kepada kelompok sasaran sehingga tingkat partisipasi rendah; dan tingkat kemandirian masyarakat rendah. Kelemahan-kelemahan tersebut, tentunya membuka ruang evaluasi agar Program Kampung KB dapat berjalan dengan lebih baik kedepannya.

Salah satu daerah dimana Program Kampung KB diimplementasikan adalah di Kota Tanjungpinang.Kampung KB adalah program yang diimplementasikan pada tahun 2016 dan tahun 2017. Program Kampung KB diimplementasikan pada 5 kelurahan di 4 kecamatan, tepatnya di: Kampung Dompak lama, Kelurahan Dompak, Kecamatan Bukit Bestari; Tanjung 
Unggat, Kelurahan Tanjung Unggat, Kecamatan Bukit Bestari; Kampung Bulang Laut, Kelurahan Kampung Bulang, Kecamatan Tanjungpinang Timur; Kampung Sei Ladi, Kelurahan Kampung Bugis, Kecamatan Tanjungpinang Kota; dan Kampung Jawa, Kelurahan Tanjungpinang Barat, Kecamatan Tanjungpinang Barat (dinkes-tanjungpinang.info). Namun, sejauh ini, walaupun Program Kampung KB sudah berjalan, studi dan literatur mengenai Program Kampung KB di Kota Tanjungpinang minim dilakukan sehingga capaian program tersebut belum diketahui.Oleh sebab itu, diperlukan sebuah studi yang dapat memberikan gambaran serta melakukan evaluasi atas Program Kampung KB di Kota Tanjungpinang.

\section{METODOLOGI}

Jenis pendekatan yang digunakan dalam penelitian ini adalah pendekatan kualitatif dengan analisa deskriptif.Pendekatan yang digunakan berupaya menyajikan gambaran yang terperinci mengenai Program Kampung KB di Kota Tanjungpinang.

Lokasi penelitian adalah di Kota Tanjungpinang, tepatnya di: Kampung Dompak lama, Kelurahan Dompak, Kecamatan Bukit Bestari; Tanjung Unggat, Kelurahan Tanjung Unggat, Kecamatan Bukit Bestari; Kampung Bulang Laut, Kelurahan Kampung Bulang, Kecamatan Tanjungpinang Timur; Kampung Sei Ladi, Kelurahan Kampung Bugis, Kecamatan Tanjungpinang Kota; dan Kampung Jawa, Kelurahan Tanjungpinang Barat, Kecamatan Tanjungpinang Barat. Alasan pemilihan lokasi tersebut adalah karena Program Kampung KB di Kota Tanjungpinang terpusat di 5 kelurahan dan 4 kecamatan dimaksud.

Data primer pada penelitian ini bersumber dari pengumpulan data kuantitatif dan data kualitatif. Data primer diperoleh dari aksi pengumpulan data terhadap Penyuluh Keluarga Berencana (PKB), Petugas Lapangan Keluarga Berencana (PLKB), tokoh masyarakat, masyarakat peserta KB, masyarakat bukan peserta KB, pemerintah desa/kelurahan, pemerintah daerah atau pihak-pihak lainnya yang memiliki informasi atau sebagai sumber rujukan informasi utama penelitian. Sedangkan data sekunder merupakan data yang didapat dari pihak lainnya atau dari sumber lainnya yang tersedia sebelum dan selama penelitian dilakukan.Data sekunder dapat berupa literatur, jurnal, video, dokumen, atau dokumentasi dari sumber lainnya yang relevan dengan penelitian. 
Penelitian ini menggunakan dua metode pengumpulan data, yakni: wawancara dan kuesioner. Metode wawancara dilakukan terhadap koordinator Penyuluh Keluarga Berencana, koordinator Petugas Lapangan Keluarga Berencana, tokoh masyarakat, pemangku adat, pejabat pemerintah desa/kelurahan, pejabat pemerintah daerah serta pihak-pihak terkait lainnya yang menjadi key informant penelitian. Metode survey dilakukan dengan menggunakan kuesioner untuk menjaring data dari responden penelitian. Responden penelitian adalah PKB, PLKB, tokoh masyarakat, masyarakat peserta KB, masyarakat bukan peserta KB, perangkat pemerintah desa/kelurahan, perangkat pemerintah daerah serta pihak-pihak terkait lainnya yang menjadi responden penelitian.

Penelitian ini menggunakan teknik cluster sampling (sampling kluster) yaitu metode penarikan sampel berkelompok dimana setiap elemen di dalam kelompok dipilih atau ditetapkan sebagai anggota sampel (Wibisono di dalam Sudaryono, 2017).Pertimbangan pengambilan teknik sampel ini karena wilayah populasi yang cukup besar dengan berbasis wilayah kecamatan, sehingga sampel yang dipilih merupakan klaster dalam bentuk kelompok Kampung KB di masing-masing kecamatan. Pada masing-masing kecamatan, sampel kemudian diambil berdasarkan Kampung KB yang berdiri di kecamatan tersebut, sehingga terpilih klaster di Kecamatan Bukit Bestari yaitu Kampung KB Kelurahan Dompak dan Kampung KB Keluruhan Tanjung Unggat, kemudian klaster di Kecamatan Tanjungpinang Barat yaitu pada Kampung KB Kelurahan Tanjungpinang Barat, klaster Kecamatan Tanjungpinang Timur yaitu Kampung KB Kelurahan Kampung Bulang, klaster Kecamatan Tanjungpinang Kota yaitu pada Kampung KB Kelurahan Tanjungpinang Kota. Kampung KB dari klaster Kampung KB tersebut, diambil sampel sebanyak 15 orang anggota klaster berdasarkan Kampung KB sehingga total anggota klaster di empat kecamatan sebanyak 75 orang. Teknik samping ini juga dapat disebut dengan area sampling yaitu teknik pengambilan sampling berdasarkan suatu bagian tertentu dari sebuah kota, daerah atau wilayah tertentu dari sebuah negara (Wibisono di dalam Sudaryono, 2017).

Dalam melakukan evaluasi terhadap Program Kampung KB di Kota Tanjungpinang, penelitian ini menggunakan Indikator Keberhasilan Program Kampung KB yang didasarkan pada dokumen Petunjuk Teknis Kampung KB Tahun 2015. Terdapat 3 indikator utama: 
Keberhasilan Input, Keberhasilan Proses, dan Keberhasilan Output. Masing-masing indikator utama akan dijabarkan dan dioperasionalkan menjadi: 1) Pedoman Wawancara untuk pengumpulan data melalui wawancara; dan 2) Daftar Pertanyaan Utama untuk pengumpulan data melalui kuesioner. Pertanyaan pada kuesioner adalah gabungan dari pertanyaan terbuka dan pertanyaan tertutup.

Data yang dijaring melalui metode-metode pengumpulan data kemudian akan dianilisa secara kualitatif dengan cara: pertama, mereduksi data dimana data yang dikumpulkan dirangkum, dipilah dan dikelompokkan dengan memfokuskan pada hal-hal penting dan relevan dengan tujuan penelitian; kedua, penyajian data dimana data yang telah direduksi disajikan secara kualitatif atau kuantitatif dalam bentuk uraian singkat, bagan hubungan, atau secara naratif; dan ketiga, pengambilan kesimpulan, dimana data yang telah disajikan ditarik kesimpulannya.

\section{HASIL PENELITIAN DAN PEMBAHASAN}

\section{Identitas Responden}

Bagian ini menjabarkan identitas responden yang dijaring melalui kuesioner penelitian. Jumlah responden yang dijaring adalah 75 responden yang terdiri dari: 15 responden dari Kampung Dompak lama; 15 responden dari Tanjung Unggat; 15 responden dari Kampung Bulang Laut; 15 responden dari Kampung Sei Ladi; dan 15 responden dari Kampung Jawa.

\section{a. Jenis Kelamin Responden}

Berdasarkan jawaban yang diberikan, dapat diketahui bahwa, responden berjenis kelamin laki-laki berjumlah 13 orang (17\% responden) dan responden berjenis kelamin perempuan berjumlah 62 orang (83\% responden).

\section{b. Pekerjaan Responden}

Berdasarkan jawaban yang diberikan, pekerjaan responden paling dominan adalah mengurus rumah tangga (44 responden/58\% responden), beragam pekerjaan lainnya (12 responden/16\% responden), pedagang ( 9 responden/12\% responden), tidak bekerja ( 8 responden/11\% responden) dan nelayan (2 responden/3\% responden). 


\section{Keberhasilan Input}

Keberhasilan Input Kampung KB ditandai dengan jumlah Penyuluh Keluarga Berencana /Petugas Lapangan Keluarga Berencana (PKB/PLKB) dan Pembantu Pembina Keluarga Berencana Desa/Sub-Pembantu Pembina Keluarga Berencana Desa (PPKBD/Sub-PPKBD) yang proporsional, ketersediaan dukungan operasional (anggaran) untuk Program KKBPK di Kampung KB dari Anggaran Pendapatan dan Belanja Negara (APBN), Anggaran Pendapatan dan Belanja Daerah (APBD), Anggaran Dana Desa (ADD), Corporate Social Responsibility (CSR), Program Keluarga Harapan (PKH) maupun sumber dana lainnya, serta ketersediaan sarana operasional maupun sarana pendukung lainnya.

\section{a. Proporsi PKB/PLKB dan Proporsi PPKBD/Sub-PPKBD}

Berdasarkan jawaban yang diberikan, 65 responden atau sebanyak 87\% responden menyatakan bahwa jumlah PKB/PLKB di Kampung KB sudah proporsional, sedangkan 10 responden atau sebanyak $13 \%$ responden merasa bahwa jumlah PKB/PLKB belum proporsional di Kampung KB.

Disamping PKB/PLKB, di Kampung KB juga dibentuk PPKBD/Sub-PPKBD untuk membantu tugas dan kerja PKB/PLKB. Berdasarkan jawaban yang diberikan, 74 responden atau 99\% responden menyatakan bahwa di Kampung KB dibentuk PPKBD/Sub-PPKBD dengan 1 responden atau hanya $1 \%$ responden merasa bahwa tidak ada pembentukan PPKBD/Sub-PPKBD.

84\% responden (63 responden) juga merasa bahwa PPKBD/Sub-PPKBD yang berperan dalam membantu tugas-tugas PKB/PLKB sudah proporsional.Namun begitu, 12 responden (16\% responden) merasa bahwa PPKBD/Sub-PPKBD perlu ditingkatkan jumlahnya agar proporsional.

Hasil wawancara menegaskan bahwa jumlah PKB/PLKB proporsional bagi tiap-tiap Kampung KB.Namun, tetap dirasa perlu penambahan jumlah PKB/PLKB dimasingmasing Kampung KB untuk mempercepat penetrasi Program KKBPK ke masyarakat.Hal ini mengingat bahwa cakupan wilayah Kampung KB yang cukup luas serta jumlah penduduk yang perlu dibina juga cukup banyak.Pembentukan PPKBD/SubPPKBD di setiap RW di masing-masing Kampung KB juga membantu tugas dan fungsi 
PKB/PLKB.Hanya saja, jumlah PPKBD/Sub-PPKBD dirasa masih kurang karena seharusnya dibentuk di setiap RT di masing-masing Kampung KB.Kesulitan untuk mencari kader, minimnya anggaran, serta keengganan masyarakat untuk berpartisipasi adalah tantangan yang dihadapi dilapangan.

\section{b. Dukungan Operasional}

Tersedianya dukungan operasional seperti anggaran, adalah salah satu indikator input yang sangat penting bagi keberhasilan Program Kampung KB. Namun, berdasarkan jawaban yang diberikan, dukungan operasional anggaran untuk kegiatan Program KKPBK di Kampung KB tersedia, adalah 18 responden atau 24\% responden, sedangkan responden yang menyatakan bahwa dukungan operasional anggaran tersebut tidak tersedia, adalah 57 responden atau $76 \%$ responden.

Berdasarkan jawaban yang diberikan, dukungan operasional anggaran yang tersedia untuk pembiayaan kegiatan Program KKPBK di Kampung KB bersumber dari APBD (12 responden), anggaran kelurahan (5 responden) dan sumber anggaran lainnya (1 responden).Berdasarkan jawaban yang diberikan, dukungan operasional anggaran yang tidak tersedia untuk pembiayaan kegiatan Program KKPBK di Kampung KB, diharapkan dapat bersumber dari APBD (33 responden), anggaran kelurahan (18 responden), iuran warga (3), APBN (2 responden), dan sumber anggaran lainnya (1 responden).

Hasil wawancara menegaskan bahwa dukungan anggaran untuk operasional kegiatankegiatan Program Kampung KB adalah minim atau tidak ada sama sekali. Anggaran yang tersedia umumnya dialokasikan untuk kegiatan-kegiatan seremonial maupun pertemuan forum dan mini lokakarya.Minimnya anggaran menyebabkan rencana kegiatan terkadang tidak dapat diwujudkan, seperti misalnya, wacana pembuatan kampung pelangi dan penyediaan tempat pembuangan sampah di masing-masing RW di Kampung KB Dompak Lama. Minimnya anggaran juga menciptakan tantangan tersendiri dimana PKB/PLKB terkadang menggunakan dana milik pribadi atau berharap dari swadaya masyarakat atau bantuan kelurahan untuk operasional kegiatan. Keengganan masyarakat berpartisipasi dalam kegiatan-kegiatan Kampung KB atau 
untuk menjadi kader Kampung KB sebagai PPKBD/Sub-PPKB atau terlibat dalam POKJA Kampung KB, juga dapat diatribusikan pada minimnya insentif atau stimulan finansial yang tersedia bagi kader Kampung KB.Oleh karenanya, dukungan anggaran diharapkan dapat ditingkatkan serta dapat bersumber dari Pemerintah Daerah Kota Tanjungpinang melalui ABPD sebagai salah satu stakeholder Program Kampung KB. Pemerintah daerah perlu menunjukkan peran dan kepedulian terhadap Kampung KB dengan mengalokasikan sebagian anggaran bagi operasional Kampung KB atau memfasilitasi penyaluran dana CSR dari sumber-sumber pendanaan lainnya untuk Program Kampung KB di Kota Tanjungpinang.

\section{c. Dukungan Sarana Operasional}

Tersedianya sarana operasional seperti bangunan kantor dan sarana pendukung lainnya, adalah salah satu indikator input yang sangat penting bagi keberhasilan Program KKBPK di Kampung KB. Berdasarkan jawaban yang diberikan, sarana operasional untuk menunjang Program Kampung KB tersedia (75 responden/100\% responden).

Berdasarkan jawaban yang diberikan, bentuk sarana operasional dan sarana pendukung lainnya yang tersedia untuk menunjang Program Kampung KB adalah bangunan kantor (45 resonden/60\% responden) dan obat-obatan serta alat kontrasepsi (30 responden/45\% responden).

Hasil wawancara mengungkapkan bahwa sarana operasional seperti bangunan kantor atau sekretariat Kampung KB sudah tersedia di masing-masing Kampung KB, namun dengan terbatas. Terbatasnya sarana operasional terletak pada bangunan kantor atau sekretariat Kampung KB yang menumpang pada bangunan lainnya seperti POSYANDU, POLINDES, Balai Penyuluhan, atau bangunan lainnya. Namun begitu, agar fungsi Kampung KB dapat berjalan dengan efektif, terdapat rencana untuk pemindahan atau penyatuan sekretariat Kampung KB kedepannya. Kampung KB Kampung Jawa misalnya, berencana untuk menyatukan sekretariat Kampung KB dengan Balai Penyuluhan Kelurahan Tanjungpinang Barat sedangkan Kampung KB Sei Ladi berencana untuk difasilitasi dalam bentuk penyediaan lahan dari Kelurahan Kampung Bugis. 


\section{Keberhasilan Proses}

Keberhasilan Proses ditentukan berdasarkan pada peningkatan frekuensi dan kualitas kegiatan advokasi dan KIE; peningkatan kualitas pelayanan KB dan Kesehatan Remaja (KR); pertemuan berkala kelompok kegiatan Bina Keluarga Balita (BKB), Bina Keluarga Remaja (BKR), dan Bina Keluarga Lansia (BKL), Usaha Peningkatan Pendapatan Keluarga Sejahtera (UPPKS), Institusi Masyarakat Pedesaan (IMP) maupun lokakarya mini; pelayanan Taman POSYANDU (PAUD, Kesehatan/POSYANDU dan BKB); pelayanan Surat Nikah, Akta Kelahiran, Kartu Tanda Penduduk (KTP) serta kegiatan-kegiatan lainnya.

\section{a. Kegiatan Advokasi}

Frekuensi kegiatan advokasi di Kampung KB dapat dilihat dari jawaban responden dimana kegiatan advokasi sering dilakukan (18 responden/24\% responden), kegiatan advokasi cukup sering dilakukan (10 responden/13\%responden), dan kegiatan advokasi tidak terlalu sering dilakukan (15 responden/20\% responden).Disamping frekuensi kegiatan advokasi yang cukup sering, terdapat 32 responden (43\% responden) yang merasa bahwa kegiatan advokasi tidak pernah berjalan di Kampung KB.

Hasil wawancara menunjukkan bahwa kegiatan advokasi sudah berjalan di Kampung KB dengan frekuensi yang cukup sering.Kegiatan advokasi umumnya dilakukan ke tokoh-tokoh formal di kecamatan atau di kelurahan, maupun ke tokoh-tokon informal seperti Ketua RT atau Ketua RW setempat.Bentuk kegiatan advokasi yang dilakukan di Kampung KB juga beragam dimana kegiatan yang paling umum adalah berdiskusi atau bermusyawarah antar warga di Kampung KB untuk membahas isu atau masalahmasalah kependudukan di lingkungan Kampung KB (39 responden).Disamping itu, bentuk kegiatan advokasi lainnya adalah dengan membawa isu atau masalah-masalah kependudukan ke pemangku kebijakan setempat seperti ke pihak kelurahan atau ke pihak kecamatan (4 responden).

Kualitas kegiatan juga menjadi tolak ukur keberhasilan kegiatan advokasi di Kampung KB dan Berdasarkan jawaban yang diberikan, responden menilai bahwa kegiatan advokasi sudah berjalan baik (27 responden) dan cukup baik (14 responden).Namun, kegiatan advokasi masih perlu meningkatkan kualitasnya dimana 
hal ini tercermin dari respon jawaban yang menilai bahwa kegiatan advokasi yang dilakukan di Kampung KB belum baik (2 responden).

\section{b. Kegiatan KIE}

Frekuensi kegiatan KIE di Kampung KB dapat dilihat dari jawaban responden dimana kegiatan KIE sering dilakukan (41 responden/55\% responden), kegiatan KIE cukup sering dilakukan (15 responden/20\% responden), dan kegiatan KIE tidak terlalu sering dilakukan (14 responden/19\% responden). Disamping frekuensi kegiatan KIE yang sering dilakukan, terdapat 3 responden atau $4 \%$ responden yang merasa bahwa kegiatan KIE tidak pernah berjalan di Kampung KB dan 2 responden atau 3\% responden tidak pernah mengikuti kegiatan di Kampung KB.

Kegiatan KIE umumnya dilaksanakan setiap bulan dan bervariasi antar Kampung KB.Kampung KB Sei Ladi, misalnya, melakukan kegiatan KIE yang disejalankan dengan kegiatan BKB yang diselingi dengan informasi dan edukasi mengenai keikutsertaan ber-KB bagi masyarakat.Namun, kegiatan KIE tentu memiliki tantangannya sendiri.Tantangan yang umum dihadapi adalah masyarakat terkadang tidak terlalu peduli dengan pemahaman yang diberikan oleh PKB/PLKB tentang Program KKBPK hingga pemahaman yang keliru mengenai Program KB dan alat kontrasepsi.Bentuk kegiatan KIE yang dilakukan di Kampung KB juga beragam dimana kegiatan yang paling umum adalah sosialisasi di Kampung KB (57 responden), kegiatan penyuluhan (12 responden), dan kegiatan konseling (1 responden).

Bentuk kegiatan KIE di Kampung KB umumnya mencakup masa dengan jumlah yang besar (diatas 15 peserta) di setiap kegiatan.Disamping itu, kegiatan KIE terkadang dilakukan secara perorangan (5 responden), dan secara berkelompok antara 2-15 peserta (3 responden) tergantung dari jenis kegiatan.

Kualitas kegiatan juga menjadi tolak ukur keberhasilan kegiatan KIE di Kampung KB dan berdasarkan jawaban yang diberikan, responden menilai bahwa kegiatan KIE sudah berjalan baik (54 responden) dan cukup baik (16 responden). 


\section{c. Pelayanan Keluarga Berencana}

Frekuensi pelayanan KB dapat dilihat dari jawaban responden dimana pelayanan KB sering dilakukan (43 responden/57\% responden), pelayanan KB cukup sering dilakukan (14 responden/19\% responden), dan pelayanan KB tidak sering dilakukan (11 responden/15\% responden). Disamping frekuensi pelayanan KB yang sering dilakukan, terdapat 7 responden atau 9\% responden yang merasa bahwa pelayanan KB tidak pernah dilakukan di Kampung KB.

Pelayanan KB umumnya disejalankan dengan kegiatan atau hari-hari besar nasional.Seperti misalnya, kegiatan pelayanan KB keliling dimana pelayanan KB diberikan disetiap PUSKESMAS di Kota Tanjungpinang, atau pada saat Hari Kesehatan Nasional (HKN).Hanya saja, terkadang terdapat kendala-kendala dalam kegiatan pelayanan $\mathrm{KB}$ seperti kesulitan untuk meyakinkan masyarakat mengenai manfaat menggunakan alat kontrasepsi untuk membatasi angka kelahiran terutama untuk jenis kontrasepsi non-hormonal.Hal ini terjadi karena pemahaman yang keliru mengenai alatalat kontrasepsi non-hormonal seperti IUD, implan, maupun alat kontrasepsi nonhormonal lainnya.

Bentuk pelayanan KB yang dilakukan di Kampung KB juga beragam dimana pelayanan yang paling umum adalah konseling tentang KB dan alat kontrasepsi (42 responden), pemeriksaan ibu hamil, ibu menyusui, dan imunisasi (18 responden), pemasangan alat kontrasepsi (5 responden), promosi KB ke Pasangan Usia Subur (1 responden), sedangkan 2 responden tidak pernah mengikuti pelayanan KB.

Kualitas pelayanan juga menjadi tolak ukur keberhasilan pelayanan KB di Kampung $\mathrm{KB}$ dan berdasarkan jawaban yang diberikan, responden menilai bahwa pelayanan $\mathrm{KB}$ sudah berjalan dengan baik (56 responden) dan cukup baik (10 responden).Namun, pelayanan KB masih perlu meningkatkan kualitasnya dimana hal ini tercermin dari respon jawaban yang menilai bahwa pelayanan KB yang dilakukan di Kampung KB belum baik (2 responden). 


\section{d. Pelayanan Kesehatan Reproduksi}

Frekuensi pelayanan KR dapat dilihat dari jawaban responden dimana pelayanan KR sering dilakukan (11 responden/15\% responden), pelayanan KR cukup sering dilakukan (7 responden/9\% responden), pelayanan KR tidak sering dilakukan (16 responden/21\% responden), dan pelayanan $\mathrm{KR}$ sangat tidak sering (2 responden/3\% responden). Disamping frekuensi pelayanan KR yang tidak sering dilakukan, terdapat 39 responden atau $52 \%$ responden yang merasa bahwa pelayanan KR tidak pernah dilakukan di Kampung KB.

Bentuk pelayanan KR di Kampung KB juga beragam dimana pelayanan yang paling umum dilakukan adalah sosialisasi dan konseling kesehatan reproduksi (35 responden), dan penyuluhan tentang narkoba (1 responden).

Kualitas pelayanan juga menjadi tolak ukur keberhasilan pelayanan KR di Kampung $\mathrm{KB}$ dan berdasarkan jawaban yang diberikan, responden menilai bahwa pelayanan $\mathrm{KR}$ sudah berjalan dengan baik (26 responden) dan cukup baik ( 9 responden).Namun, pelayanan KR masih perlu meningkatkan kualitasnya dimana hal ini tercermin dari respon jawaban yang menilai bahwa pelayanan KR yang dilakukan di Kampung KB belum baik (1 responden).

\section{e. Pertemuan Berkala POKTAN}

Pertemuan berkala Kelompok Kegiatan adalah pertemuan yang dilakukan oleh Kelompok Kegiatan (POKTAN) BKB, BKR, BKL, UPPKS, IMP, lokakarya mini dan POKTAN lainnya.Pertemuan berkala POKTAN tersebut dinilai berdasarkan frekuensi pertemuan dan POKTAN yang paling aktif melakukan pertemuan-pertemuan berkala.Berdasarkan jawaban yang diberikan, pertemuan berkala POKTAN sangat sering dilakukan (1 responden), sering dilakukan (67 responden), dan cukup sering dilakukan (6 responden).Namun, terdapat 1 responden yang merasa bahwa POKTAN tidak pernah melakukan pertemuan berkala di Kampung KB.

Berdasarkan jawaban yang diberikan, POKTAN yang paling aktif dengan melakukan pertemuan berkala di Kampung KB adalah POKTAN BKB (74 responden). 


\section{Keberhasilan Output}

\section{a. Pendataan Keluarga}

Ketua Rukun Tetangga (RT)/Ketua Rukun Warga (RW) diharapkan memiliki data dan peta keluarga yang bersumber dari pendataan keluarga.Oleh karenanya, RT/RW diharapkan dapat melakukan pendataan keluarga di Kampung KB. Berdasarkan jawaban yang diberikan, responden yang menyatakan bahwa RT/RW melakukan pendataan keluarga adalah 48 responden atau 64\% responden, sedangkan responden yang menyatakan bahwa RT/RW tidak melakukan pendataan keluarga adalah 27 responden atau $36 \%$ responden.

Bentuk data yang dikumpulkan dengan pendataan keluarga sangat beragam dimana bentuk data yang paling umum adalah data bantuan sosial yang diterima keluarga (17 responden), total jumlah penduduk ( 9 responden), rumah tidak layak huni (7 responden), jumlah balita, remaja, dan lansia dalam keluarga (5 responden), Jumlah anggota keluarga (5 responden), keikutsertaan keluarga dalam Program KB (3 responden), pendatang baru (1 responden), dan tingkat kesejahteraan keluarga (1 responden).

\section{b. Peserta KB Aktif}

Berdasarkan jawaban yang diberikan, responden yang menyatakan ikut sebagai peserta KB aktif adalah 32 responden atau $43 \%$ responden, sedangkan responden yang menyatakan tidak ikut sebagai peserta KB aktif adalah 43 responden atau 57\% responden.

Metode KB yang digunakan oleh responden peserta aktif KB adalah implan bawah kulit/susuk (13 responden), suntik KB (12 responden), pil KB (5 responden), kondom (1 responden), dan metode KB lainnya (1 responden).

\section{c. Balita dalam Keluarga}

Berdasarkan jawaban yang diberikan, responden yang memiliki balita dalam keluarga adalah 39 responden atau 52\% responden, sedangkan responden yang tidak memiliki balita dalam keluarga adalah 36 responden atau $48 \%$ responden.

Dari 39 responden yang memiliki balita dalam keluarga, 33 responden atau $85 \%$ responden berpartisipasi dalam Kelompok Kegiatan BKB di Kampung KB, sedangkan 6 
responden atau 15\% responden tidak berpartisipasi. Dari 33 responden yang berpartisipasi dalam Kelompok Kegiatan BKB, 29 responden menilai bahwa Kelompok Kegiatan BKB di Kampung KB sudah berjalan dengan baik, sedangkan 4 responden menilai bahwa Kelompok Kegiatan BKB di Kampung KB sudah berjalan dengan cukup baik.

\section{d. Remaja dalam Keluarga}

Berdasarkan jawaban yang diberikan, responden yang memiliki remaja dalam keluarga adalah 48 responden atau 64\% responden, sedangkan responden yang tidak memiliki remaja dalam keluarga adalah 27 responden atau 36\% responden. Dari 48 responden yang memiliki remaja dalam keluarga, 3 responden atau hanya $6 \%$ responden berpartisipasi dalam Kelompok Kegiatan BKR di Kampung KB, sedangkan 45 responden atau 94\% responden tidak berpartisipasi. Dari 3 responden yang berpartisipasi dalam Kelompok Kegiatan BKR, 3 responden menilai bahwa Kelompok Kegiatan BKR di Kampung KB sudah berjalan dengan baik.

Dari 48 responden yang memiliki remaja dalam keluarga, 7 responden atau hanya $15 \%$ responden memiliki remaja yang berpartisipasi dalam kegiatan Pusat Informasi Kegiatan-Remaja (PIK-R) Kampung KB, sedangkan 41 responden atau $85 \%$ responden lainnya, memiliki remaja dalam keluarga namun tidak berpartisipasi dalam kegiatan PIK-R Kampung KB.

\section{e. LANSIA dalam Keluarga}

Berdasarkan jawaban yang diberikan, responden yang memiliki lansia dalam keluarga adalah 24 responden atau 32\% responden, sedangkan responden yang tidak memiliki lansia dalam keluarga adalah 51 responden atau 68\% responden. Dari 24 responden yang memiliki lansia dalam keluarga, 14 responden atau 58\% responden berpartisipasi dalam Kelompok Kegiatan BKL di Kampung KB, sedangkan 9 responden atau 42\% responden lainnya tidak berpartisipasi.

Dari 14 responden yang berpartisipasi dalam Kelompok Kegiatan BKL, 14 responden menilai bahwa Kelompok Kegiatan BKL di Kampung KB sudah berjalan dengan baik. 


\section{f. Penilaian Program Kampung KB}

Responden yang menilai bahwa Program Kampung KB sudah berjalan dengan baik adalah 41 responden (55\% responden), sudah berjalan dengan cukup baik 31 responden, dan tidak berjalan dengan baik 3 responden.

\section{KESIMPULAN DAN SARAN}

\section{Kesimpulan}

Kesimpulan penelitian ini adalah sebagai berikut:

a. Pengetahuan dan pemahaman masyarakat Kampung KB tentang Program Kampung KB beragam namun terbatas. Program Kampung KB dipersepsikan sebagai program pengendalian jumlah anak serta identik dengan alat kontrasepsi/alat KB, sedangkan aspek kependudukan, pembangunan keluarga, maupun aspek lintas sektor Kampung KB diketahui dan dipahami namun dengan terbatas.

b. Pengetahuan dan pemahaman masyarakat Kampung KB tentang Program Kampung KB bersumber dari kegiatan-kegiatan yang dilaksanakan oleh PKB/PLKB di Kampung KB. Kegiatan seperti sosialiasi mengenai Program Kampung KB, pertemuan forum-forum di Kampung KB, kegiatan lokakarya dan pelatihan, kegiatan Tri Bina (BKB, BKR, dan BKL) Kampung KB, kegiatan gotong royong dan kebersihan lingkungan, kegiatan PKK, majelis taklim dan remaja masjid, serta kegiatan-kegiatan lainnya, menjadi sumber pengetahuan masyarakat mengenai Program Kampung KB.

c. Masyarakat Kampung KB menerima pelayanan KB dan pelayanan kesehatan disamping mengikuti kegiatan-kegiatan yang dilaksanakan di Kampung KB. Kegiatan lintas sektor seperti pendataan dan pembuatan akte kelahiran dan Kartu Tanda Penduduk (KTP) berkerjasama dengan Dinas Kependudukan dan Catatan Sipil (DISDUK CAPIL) Kota Tanjungpinang, seperti yang dilakukan di Kampung KB Tanjung Unggat dan Kampung Dompak Lama, adalah salah satu contoh bentuk kerjasama lintas sektor yang melengkapi pelayanan dan kegiatan Program Kampung KB. Namun, cakupan kegiatan-kegiatan Kampung KB perlu diintensifkan agar dapat menjangkau lebih banyak masyarakat di Kampung KB. 
d. Minimnya dukungan anggaran adalah salah satu tantangan yang dihadapi oleh Program Kampung KB. Keengganan masyarakat untuk menjadi kader Kampung KB dalam PPKBD/Sub-PPKBD atau terlibat dalam POKJA Kampung KB, juga dapat diatribusikan pada minimnya insentif atau stimulan finansial yang tersedia.

e. Tersedianya sarana operasional seperti bangunan kantor atau sekretariat maupun sarana pendukung lainnya, adalah salah satu indikator input yang sangat penting bagi keberhasilan Program KKBPK di Kampung KB. Sarana operasional seperti bangunan sekretariat Kampung $\mathrm{KB}$ sudah tersedia di masing-masing Kampung KB, namun terbatas. Terbatasnya sarana operasional terletak pada bangunan kantor atau sekretariat Kampung KB yang menumpang pada bangunan lainnya seperti POSYANDU, POLINDES, Balai Penyuluhan, atau bangunan lainnya.

f. Kegiatan advokasi cukup sering dijalankan di Kampung KB dengan kualitas kegiatan yang dipersepsikan sudah berjalan dengan baik. Kegiatan advokasi dilakukan kepada tokoh-tokoh formal di kecamatan atau di kelurahan, maupun ke tokoh-tokoh informal seperti Ketua RT atau Ketua RW. Bentuk kegiatan advokasi adalah dengan berdiskusi atau bermusyawarah antar warga di Kampung $\mathrm{KB}$ atau dengan membawa isu atau masalah-masalah kependudukan ke pemangku kebijakan setempat.

g. Kegiatan KIE sering dijalankan di Kampung KB dengan kualitas kegiatan yang dipersepsikan sudah berjalan dengan baik. Kegiatan KIE umumnya dilaksanakan setiap bulan dengan peserta lebih dari 15 orang pada tiap-tiap kegiatan. Kegiatan KIE bervariasi antar Kampung KB dimana kegiatan yang paling sering dijalankan adalah kegiatan sosialisasi. Kegiatan KIE memiliki tantangan yang umum dihadapi seperti: masyarakat Kampung KB yang terkadang tidak acuh dengan pemahaman yang diberikan oleh PKB/PLKB tentang Program KKBPK hingga pemahaman yang keliru mengenai Program KB dan alat kontrasepsi sehingga pemahaman yang keliru tersebut perlu diluruskan oleh PKB/PLKB.

h. POKTAN Kampung KB sering melakukan pertemuan berkala dan POKTAN yang paling aktif melakukan pertemuan berkala adalah POKTAN BKB. 
i. Program Kampung KB di Kota Tanjungpinang dinilai sudah berjalan dengan baik. Hal ini ditandai dengan jumlah responden yang secara mayoritas menyatakan bahwa Program Kampung KB sudah berjalan dengan baik.

\section{Saran}

Saran penelitian ini adalah sebagai berikut:

a. Kampung KB di Kota Tanjungpinang dapat dikembangkan melalui pendekatan kebudayaan, yaitu dengan mewujudkan Kampung KB Berbudaya. Kegiatan yang dapat dilakukan adalah dengan membentuk kelompok-kelompok kegiatan sanggar kesenian baik rebana, kompang, sanggar tari, maupun sanggar kesenian lainnya.

b. Kampung KB Kota Tanjungpinang dapat dikembangkan melalui pendekatan ekonomi kerakyatan dengan mewujudkan Kampung KB mandiri. Kegiatan yang dapat dilakukan adalah dengan cara membina UPPKS Kampung KB dalam bentuk usaha, seperti: kuliner khas Melayu, usaha anyaman tikar, kerajinan khas masing-masing Kampung KB atau kerajinan khas Tanjungpinang.

c. Kampung KB diharapkan dapat bersinergi dan menjadi prioritas Pemerintah Daerah Provinsi Kepulauan Riau, BKKBN Provinsi Kepulauan Riau, BKKBN Perwakilan Provinsi Kepulauan Riau, Pemerintah Daerah Kota Tanjungpinang, serta pemangku kepentingan lainnya. Diharapkan dengan sinergitas dan prioritas, Kampung KB dapat aktif dan menjangkau masyarakat lebih luas dengan dukungan pemerintah daerah dan swadaya masyarakat dalam rangka pemberdayaan masyarakat dengan skema Kampung KB.

\section{UCAPAN TERIMAKASIH (ACKNOWLEDGMENT)}

Penghargaan dan ucapan terimakasih yang sebesar-sebesarnya disampaikan kepada Badan Kependudukan dan Keluarga Berencana Nasional (BKKBN) Perwakilan Provinsi Kepulauan Riau atas partisipasi, dukungan, serta kerjasama penelitian yang dilakukan bersama STISIPOL Raja Haji. BKKBN Perwakilan Provinsi Kepulauan Riau telah berjasa dalam memberikan masukan yang tidak ternilai, kritik dan saran yang membangun serta memfasilitasi beragam rangkaian kegiatan sehingga penelitian ini dapat terlaksana dengan baik. 


\section{REFERENSI}

Badan Kependudukan dan Keluarga Berencana Nasional (2015).Rencana Strategis Badan Kependudukan dan Keluarga Berencana Nasional Tahun 2015-2019. Jakarta. Badan Kependudukan dan Keluarga Berencana Nasional.

Badan Kependudukan dan Keluarga Berencana Nasional (2017). Review Program Kependudukan, Keluarga Berencana dan Pembangunan Keluarga Tahun 2017: Provinsi Sumatera Barat. Padang: Perwakilan BKKBN Provinsi Sumatera Barat.

Badan Kependudukan dan Keluarga Berencana Nasional (2015). Petunjuk Teknis Kampung Keluarga Berencana. Jakarta: Badan Kependudukan dan Keluarga Berencana Nasional.

Badan Pusat Statistik Kota Tanjungpinang (2018).Kecamatan Bukit Bestari dalam Angka 2018. Tanjungpinang: Badan Pusat Statistik.

Badan Pusat Statistik Kota Tanjungpinang (2018).Kecamatan Tanjungpinang Barat dalam Angka 2018. Tanjungpinang: Badan Pusat Statistik.

Badan Pusat Statistik Kota Tanjungpinang (2018).Kecamatan Tanjungpinang Kota dalam Angka 2018. Tanjungpinang: Badan Pusat Statistik.

Badan Pusat Statistik Kota Tanjungpinang (2018).Kecamatan Tanjungpinang Timur dalam Angka 2018. Tanjungpinang: Badan Pusat Statistik.

Dinas Kesehatan dan Pengendalian Penduduk Kota Tanjungpinang. Kampung KB Kota Tanjungpinang (diakses pada: 5 November 2018 dilaman http://dinkestanjungpinang.info/index.php/142-berita/843-kampung-kb-kota-tanjungpinang)

Mardiyono (2017). Kampung KB Sebagai Upaya Pemberdayaan Masyarakat/Keluarga di Jawa Timur. Jurnal Cakrawala. Vol. 11, No. 2, Desember 2017, hal.129-136.

Mutrofin (2014). Evaluasi Program: Teks Pilihan Untuk Pemula. Yogyakarta: LaksBang PRESSIndo.

Republik Indonesia (2009). Undang-Undang Republik Indonesia Nomor 52 Tahun 2009 Tentang Perkembangan Kependudukan dan Pembangunan Keluarga. Lembaran Negara Republik Indonesia Tahun 2009, Nomor 161. Jakarta: Sekretariat Negara Republik Indonesia. 
Sardjo, S., Darmajanti, L., Boediono, K. (2017).Implementasi Model Evaluasi Formatif Program Pembangunan Sosial. Jakarta: Obor.

Setiawati, E. (2017). Persepsi Masyarakat Terhadap Program Kampung Keluarga Berencana di Kelurahan Pantoloan Boya Kecamatan Tawaeli.E-Journal Geo-Tadulako UNTAD.Vol. 5, Nomor.1 Tahun 2017.

Subarsono, A. G. (2006). Analisis Kebijakan Publik. Yogyakarta: Pustaka Pelajar.

Sudaryono (2017). Metodologi Penelitian. Jakarta: Raja Grafindo Persada.

Sugiyono (2017). Metode Penelitian Kebijakan. Bandung: Alfabeta.

Zuhriyah, A., Indarjo, S., Raharjo, B. (2017). Kampung Keluarga Berencana dalam Peningkatan Efektivitas Program Keluarga Berencana.Higeia Journal of Public Health Research and Development.Vol. 1, Nomor.4 Tahun 2017, hal 1-13. 